\title{
Forty years of declining burglary in the United States: Explanation and evidence relating to the security hypothesis
}

\section{Graham Farrell ${ }^{1}$ (D)}

Accepted: 15 January 2021 / Published online: 20 February 2021

(C) The Author(s) 2021

\begin{abstract}
Residential burglary in the United States has declined by over $80 \%$ across the last four decades, representing a major social phenomenon that remains largely unexplained. International research indicates a need for investigation of the security hypothesis. Here, 50 years of studies are examined chronologically. A consistent narrative emerges which indicates that household security, largely absent in the 1970s, improved gradually over time. Improvement occurred via several mechanisms: the increased prevalence, quality, coverage, and routine use of security fixtures and fittings. In addition, crime displacement declined over time as fewer households offered easy crime opportunities, and the average age of burglars increased as juveniles found burglary increasingly difficult. Hence the study concludes that gradual household security improvements played a central role in the decline in residential burglary. While the findings suggest a considerable revison is needed to our understanding of burglary and burglars, the likelihood that 50 years of diverse burglary research points in the same direction by chance, and without significant contrary evidence, seems remote. Further implications for theory, policy, and research are identified.
\end{abstract}

Keywords Burglary $\cdot$ Property crime $\cdot$ Crime decline $\cdot$ Crime drop $\cdot$ Juvenile crime . Security hypothesis $\cdot$ Securitization

\section{Introduction}

Residential burglary imposes significant financial and emotional costs on victims, their families and friends, and on society in general (Brown and Harris 1989; Shover 1991; Winkel and Vrij 1993; Miller et al. 1996; Cohen 2000; Beaton et al.

Graham Farrell

g.farrell@leeds.ac.uk

1 School of Law, University of Leeds, Leeds LS2 9JT, UK

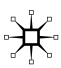


2000; Wickramasekera et al. 2015). The monetary costs include the replacement of stolen goods, repairs to damaged property, and the cost of the time to organize those activities. The monetary costs are often exceeded by the nonmonetary emotional and psychological costs to individuals and families of the intrusion and trespass. This violation and defilement of their property results in anger, shock, fear and difficulty sleeping (Budd 1999). The additional costs to society include the monetary costs of policing, criminal justice and private precautionary responses, health and psychological services, and the cost of the fear of crime engendered. Further, there are numerous cost multipliers from precursor and subsequent crimes. This can include theft of a vehicle for travel to commit a suburban burglary and transport stolen goods. Burglary can also escalate when household occupants are present, and can result in assault and rape, with Shover (1991, p. 78) concluding that " $[\mathrm{t}]$ he potential for physical harm to its victims places burglary near the top of offenses most feared by its citizens". Burglary cost are also multiplied via the further damage to society caused by re-sale markets for stolen goods, illicit drug markets that are funded by the proceeds of burglary, and violence associated with those markets (Felson and Clarke 1998). Longer-term costs are also incurred due to the progression along criminal careers that can occur when juveniles succeed in burglary (Owen and Cooper 2013), and due to the reduced employment and life prospects experienced by crime victims (Macmillan 2000).

Investigating two decades of increasing burglary rates following the Second World War, the 1967 President's Commission on Law Enforcement and the Administration of Justice concluded that

People can do much to insure their own safety and that of their families and belongings by reducing the opportunities for crime. Many crimes would not occur if individuals had proper locks on their doors and windows and enough lighting to discourage prowlers....

(President's Commission on Law Enforcement and Administration of Justice 1967, p. 288)

The sixfold increase in the residential burglary rate from the 1940s to the 1970s brought further attention, a subsequent Bureau of Justice Statistics (BJS) report concluding that:

Household burglary ranks among the more serious felony crimes...[B]urglary is potentially a far more serious crime than its classification as a property offense indicates; for many victims, including those that avoid the trauma of personal confrontation, the invasion of their home on one or more occasions constitutes a violation that produces permanent emotional scars. (Bureau of Justice Statistics 1985, p. 1)

Another BJS report put burglary 'at the heart' of America's crime problem:

Robbers and burglars exact heavy losses and suffering from their victims. The most numerous of the offenses that the public considers to be the most serious, many robberies and burglaries also fund illegal drug purchases. A cogent argu- 
Fig. 1 Burglaries per 1000 households (Source: NCVS, UCR, US Census)

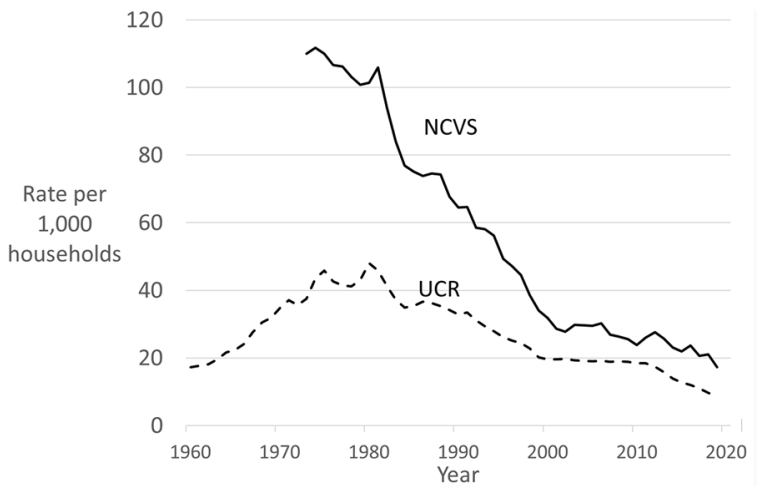

ment can be made that controlling the incidence of these two crimes would strike at the heart of criminal behavior in the United States. (Perez 1992, p. 1)

and a third categorized burglary as of 'high national concern':

Of the crimes measured by the NCVS [National Crime Victimization Survey], many people find burglaries and violent crimes committed by strangers to be especially threatening. For the purposes of this report, these crimes have been termed crimes of high concern. (Bastion 1992, p. 8, emphasis in original)

By that time, however, the burglary rate was already in decline. And the decline continued such that, at the time of writing, it has been the dominant trend for between four and five decades (Rand et al. 1997; Walters et al. 2013; Fig. 1). Burglaries per household recorded by the police as the Uniform Crime Reports (UCR) declined 81.9\% between 1980 and 2019. The National Crime Victimization Survey (NCVS), which includes crimes not reported to the police, estimated an $83.0 \%$ decline between 1980 and 2019, or $84.6 \%$ if 1974 is taken as the reference year (Fig. 1). ${ }^{1}$

A lack of research seeking to explain the decline in residential burglary was apparent two decades ago, when a National Institute of Justice researcher, writing in this journal, observed that "In contrast to the media and scholarly interest given to the recent drop in homicide rates and other violent crimes has been [an] almost complete lack of attention paid to the 25-year decline in US residential burglary rates..." (Titus 1999, p. 60). Some more recent studies of the violent crime drop do examine burglary. However, they largely focus on the violent crime drop from the early to mid-1990s when violence peaked, overlooking how burglary declined from the 1970 s or early 1980 s. Further, most such attempts to explain the crime

\footnotetext{
1 The National Crime Victimization Survey (NCVS) is the most reliable source on residential burglary trends, measuring it from 1973 onwards, while burglaries reported to and recorded by the police, collated nationally by the FBI as the Uniform Crime Reports (UCR) are available for longer. The trends track each other reasonably well over time (Biderman and Lynch 1991; Lynch and Addington 2007; Lauritsen et al. 2016). The household rates used here are based on the number of households estimated by the US Census Bureau.
} 
decline from the 1990s have been found lacking: There is little or no sound evidence to uphold propositions that crime declined due to, for example, increased imprisonment, changes to policing, changes to abortion law, illicit drug markets, demographic change, childhood lead poisoning, and so on, and so such hypotheses are not the focus here because they are taken to have been largely falsified (Farrell 2013; Farrell et al. 2014).

The focus here is the security hypothesis, for which there is significant supporting evidence in relation to the international crime drop for other countries and crime types. A series of international studies find that crime declined because of security improvements, and did so without much, if any, crime displacement. The evidence is largely unequivocal in relation to vehicle crime, with strong corroborating evidence from Australia, England and Wales, Germany, the Netherlands, and to some extent the US. Improvements to vehicle security, particularly the electronic immobilizer and door deadlocks, were responsible for the decline in auto theft in those countries (Kriven and Ziersch 2007; Bässmann 2011; Farrell et al. 2011; Fujita and Maxfield 2012; Brown 2015a, b; van Ours and Vollaard 2016; Dixon and Farrell 2020). The role of household security devices in declining residential burglary has not been subject to as much empirical study, but the existing work of most relevance is a series of British studies. These studies are discussed in more detail later but conclude that household security improvements, particularly improved door and window locks and security lighting, are largely responsible (Tilley et al. 2011, 2015a; Tseloni et al. 2016, 2017). The British studies benefitted from the Crime Survey for England and Wales, which collated several decades' information on household security device usage. Such information has not, to this author's knowledge, been collected in national victim surveys relating to the United States. There are, however, research studies relating to the US which contain some information about household security. The present study seeks to identify and synthesize that information, aiming to piece together a picture from five decades of diverse burglary studies.

The main theoretical reference points for this study are routine activities and rational choice, situational crime prevention and the security hypothesis. However, once these have been introduced briefly in this section, the focus is mainly on the evidence. The routine activities perspective indicates the importance of target suitability, the capability of guardianship, and how often and where they converge with potential offenders in order for crime to occur (Cohen and Felson 1979). Offender decisions are taken to operate within the framework of bounded rationality (for collections see Cornish and Clarke 1986; Piquero and Tibbetts 2002), which means that offenders take crime opportunities when they perceive benefits to outweigh costs. Offenders' perceptions are subjective, and the costs and benefits of crime include monetary and non-monetary components. The perceived costs of committing residential burglary include the time and effort required, the risk of arrest and punishment, the risk of bodily harm if interrupted, plus any possible emotional costs such as remorse. The perceived benefits include the monetary gain from stolen cash and fenced goods but also the benefit from excitement and feelings of power that some burglars report (Nee and Meenaghan 2006). Situational crime prevention identifies mechanisms by which crime is made more costly or less beneficial (Clarke 2012, 2017), and the mechanisms by which different security devices work are here 
interpreted within this framework. For the most part, household security devices trigger mechanisms that make burglary actually, or perceived to be, more difficult or riskier. Stronger window frames and locks, for example, harden the target and reduce access to a property, requiring time, effort and skill on behalf of offenders to overcome, or additional time and effort to identify a less secure property. Security lighting deters because it threatens detection, making residential burglary riskier, and so on (Sorensen 2003).

\section{Method}

This study collates information from previous studies of burglary and household security, and includes some supplementary analysis of burglar arrest data. Burglary studies that focus on security were identified through electronic literature searches, close examination of key burglary studies (particularly the major book-length studies), and from references in existing studies. However, it was soon apparent that household security is seldom mentioned in the title, abstract or keywords of burglary studies, and often comprises a secondary or tertiary concern. That is, in many of the major studies of burglary, including the majority of books on the subject, household security may form part of the study to varying degrees but is not the main focus. Hence these studies were examined to identify their components which relate to household security, and to identify potentially relevant further studies.

The supplementary analysis of trends in age-related burglar arrests uses data for 1980-2014 from the Bureau of Justice Statistics online arrest data tool (Snyder et al. 2017), and data from 1960 to 1979 as supplied by the FBI. It is generally accepted that, other things equal, trends in arrests are a reasonable indicator of those in offending, and there are significant precedents for using the data in the way it is used here (e.g. Blumstein et al. 1986; Farrington 1986; Snyder 2012).

Since the issue of security is often secondary or, for present purposes, 'hidden' within burglary studies that have a different primary focus, the possibility that some useful studies were not captured cannot be excluded. To that end, the corresponding author welcomes suggestions and critical comment. Methodologically, however, the key issue is whether the captured studies offer a representative picture of the history of US residential burglary and security. With respect to that issue, since the evidence comes from multiple sources and methods spanning 50 years, and appears to point in the same general direction, this affords some confidence in the representativeness of the findings. That said, it is clear that the subject will benefit from further research, and some possibilities to that end are discussed later.

\section{Findings}

\section{The extent and effectiveness of household security}

A major study of 18 areas of Boston in the early 1970s specified that, for a door to be defined as secure, for purposes of the study, it must "(1) be of metal, metal panels, 
solid wood, or hollow wood of three-quarter inch thickness, (2) have no unprotected glass near the door handle; (3) have no exposed hinges; (4) lock with either a threequarter inch dead latch or dead bolt or a vertical bolt." (Reppetto 1974, p. 67). Only $8 \%$ of households were found to have secure doors. That is, over $90 \%$ of households had at least one insecure door because " $39 \%$... were constructed of wood panel, $26 \%$.. had glass near the door handle, $8 \%$ [had] removable exterior hinges, and the remainder ... inadequate locking systems." (p. 67). Despite this, "burglary incidence did appear inversely related to ... door security.." in middle class areas (p. 68). The reason the study could not assess the effectiveness of other specific security measures is telling: There were too few to evaluate! (p. 69). The study is generally considered a landmark in the field, and indicates that good quality household security was extremely scarce at that time.

With respect to burglars, the Boston study found that "only $6 \%$ could be rated as skilled. The typical burglar was young (under 25) and opportunistic. Thus, he relied on simple tools and techniques to attack his target." (Reppetto 1984, p. 157). This squares with a Canadian review's contemporary finding that "The notion that residential burglars employ relatively unskilled types of modus operandi is consistent with the youth and inexperience of most persons committing burglary." (Waller and Okihiro 1978, p. 26). Unskilled burglary by youths is an indirect indicator of the absence of good quality household security.

A landmark study from the 1980 s found that

The most commonly used technique over the years is to "jimmie" a lock or window. All that is required is a door or window that does not have a burglar proof lock and has a little play or give in it. In the case of a window, the burglar will work the window up and down until the fastener begins to loosen. A screwdriver or prybar might be used for extra leverage. (Rengert and Wasilchick 1985, p. 91).

This identifies three important factors: the absence of security, its inadequacy, and its lack of use. The study reported that "It takes just several minutes or less for a burglar to walk through an unlocked door and walk out with valuables... Another less obvious form of carelessness is to leave the door of an attached garage open after leaving home in the car." (p. 90). However, where good quality security existed it was found effective, such that.

most of the burglars we interviewed are easily discouraged by a tough lock. With so many opportunities, many burglars will move on rather than struggle with a deadbolt lock. (Rengert and Wasilchick 1985, p. 90).

This 'moving on' by burglars when faced with good quality security identifies a further important factor: it implies a high rate of crime displacement at that time. Most households were insecure, so there were plentiful alternate targets, which meant displacement was the easy option. Note also how this indicates that good quality locks could be effective but that the problem was their scarcity.

In the early 1980 s, $42 \%$ of burglaries nationally took place without a forced entry (Bureau of Justice Statistics 1985, p. 3), suggesting entry points that were either 
without security, or were left open or unlocked. In line with this, Shover observed that "the world affords abundant poorly protected opportunities for burglars", inferred from the fact that only "7\% of [1980s] households had a burglar alarm" and these "worked properly less than half the time" (Shover 1991, p. 83). He also suggests that burglary required little expertise at the time, when discussing a New York City study finding that "in more than half the incidents the burglars' entry was either unforced or was gained simply by breaking a window or a lock." (Shover 1991, p. 84). The fact that Shover groups unforced entry together with breaking a window or lock strongly implies that break-in was trivially easy in many instances.

A New York State household survey conducted in 1983-1984 considered a wide range of area and household variables relating to guardianship and security. It used multivariate models to assess the effects of occupancy and security upon burglary and attempted burglary (Garafalo and Clarke 1992). It found that "Attempted door entries were less likely to succeed when locks were in use, when special outdoor lighting was used, and when the doors were visible to neighbors or from the sidewalk", and that "a locked door is the most important factor in thwarting an offender who tries to enter a single-family housing unit via a door." (p. 457). In the absence of occupants, the study found that security "such as locks, lights, and timers" was the most effective measure (p. 460). It also found the concurrent use of several measures was more effective. Overall this study suggests that, while rare, good quality security that was used was effective. The importance of this study is that, whereas other studies discussed so far largely emphasised the absence or poor quality of security, this study emphasised the protective role of good quality household security. It also emphasized the importance of the use or activation of that security through use of terms such as a 'locked' door rather than solely noting how many doors were fitted with locks.

A cross-national comparative study of burglary to the mid-1980s identified a higher burglary rate in the US than in Canada or the UK (Mayhew 1987). It speculated that this reflected unforced entries when doors and windows were left open in the summer due to higher temperatures and humidity in many US states (p. 46). The study thereby further recognised the importance of not just the presence but the routine use of security measures. Similarly, Winchester and Jackson (1982) reported that " $22 \%$ of the respondents admitted that on the last occasion they had left the house empty during the day they had left at least one door or window open." (p. 8). This study also identified the importance of partial security coverage, noting that:

There is no reason to think that partial security will be any more effective in preventing residential burglary than no security at all. Securing all doors into the house with mortice locks may for example provide no protection against burglary if a window is left open or protected by nothing more than a simple catch. (Winchester and Jackson 1982, p. 9)

Burglars elsewhere at this time were found to be largely undeterred by visible security measures that were easily overcome (Maguire and Bennett 1982). This was confirmed by a more extensive follow-up study which revealed that, even when a household had locks, seven in ten burglars were not deterred because those locks were easily overcome. Further, and consistent with the findings of Rengert and 
Wasilchick discussed above, the remaining offenders reported that they typically displaced to another household because of the widespread availability of targets without good locks (Bennett and Wright 1984). ${ }^{2}$ Note, however, that those offenders who displaced also reported avoiding 'Chubb locks', 'special' and 'difficult' locks (p. 83). Therefore, this also strongly suggests the importance of the quality of security measures, impacting upon offender decision-making relating to both initial target selection and displacement. A major study of US burglars conducted in the late 1980s also reported that "nearly one half of the burglary sites in the present study were entered through open or unlocked windows and doors." (Cromwell et al. 1991, p. 31), though such information is difficult to interpret unambiguously without additional information on the prevalence of household security.

The burglary rate had declined significantly by the time Wright and Decker (1994) conducted their classic study of St. Louis burglars. They interviewed expert burglars rather than the juvenile novices that had characterized burglary in previous years. These experts noted the effect of good quality security on their decisionmaking, one reporting that

I don't do dead bolt locks because sometimes you have to kind of kick the door, loosen it up. I don't really like playing with dead bolts cause it takes too long. On picking locks, you can't really pick a dead bolt lock. (Burglar 103, in Wright and Decker 1994, p. 122)

and another that

I wouldn't mess with a house that has storm windows. I'm not gon say I've never done a house with storm windows, but it just takes more time tryin' to do two windows. (Burglar 14 in Wright and Decker 1994, p. 98)

This is a reference to double-paned windows being more difficult to break, and it is likely that such windows also had stronger frames and a higher proportion of built-in locks. The insights provided by the St. Louis expert burglars are informative. First, the statements tend to suggest that, by the 1990s, security measures were generally playing a more prominent role in burglar decision-making. Second, if these expert burglars were deterred by good quality door and window security, we can reasonably infer an even greater effect upon youthful novices. The St. Louis study concluded that:

The burglars seemed more unwilling than unable to overcome such obstacles; they just did not want to take the extra time and effort required. Since they were under pressure to act as quickly as possible, this makes sense. Add to this the fact that those who search for burglary sites with the intention of offending "there and then" have no foolproof way to predict the likely payoff, and the aversion to well-protected places is more sensible still. Why should they

\footnotetext{
${ }^{2}$ Readers should note that the decline in burglary in the UK began at least a decade later than in the US. This suggests that British studies from the 1980s may be more comparable, in terms of the prevailing burglary trend, to those from the US in the 1970 s.
} 
invest extraordinary energy where the reward cannot be guaranteed? (Wright and Decker 1994, p. 98)

This shift in emphasis squares with the burglary rate having declined over a third between 1980 and 1990. The St. Louis expert burglars demonstrated an aversion to deadbolts and storm windows, that is, good quality security, and the prominence of these statements is consistent with increases in the prevalence, quality and use of household security.

Security improvements to already-burglarized household were found effective as part of a package of measures in the 1980s (Pease 1991; Mawby 2001), a finding corroborated by a number of studies in different developed countries through the 1990s and early 2000s (Grove et al. 2012; Bowers and Johnson 2017). One study concluded that burglar-proof windows and doors reduced burglary by a quarter in the Netherlands from 1999 (Vollaard and van Ours 2011).

By the early twenty-first century, a review of residential burglary published by the Office of Community Oriented Policing Services concluded that household security could be effective, and that:

Target-hardening makes getting into houses more difficult for burglars, and includes installing the following: sturdy doors with dead bolts; window locks, rather than latches; doublepane, storm or divided light windows, or laminated glass that is forced-entry resistant; pin locks on windows and sliding glass doors; and sliding glass door channel locks or slide bolts. ... Door security may be influenced as much by the door's sturdiness as by its lock. Regardless, residents should use, rather than simply install, security devices. (Weisel 2005, p. 28)

A quantitative analysis of victim survey data showed that physical security measures such as door and window locks were closely linked to households with lower burglary rates (Budd 1999), while a 2007 review of statistical modeling of burglary in the US concluded that

physical protection (i.e., "hardening") of homes, including locking doors, installing alarms, and light timer devices, have also been shown to correlate with burglary victimization (Miethe and McDowall 1993; Miethe and Meier 1990, 1994; Wilcox Rountree and Land 1996, Wilcox et al. 1994)." (Wilcox et al. 2007, p. 774).

The same study indicated that target hardening measures and defensible space were the most effective guardianship measures, and that physical security measures were more effective in residential areas where a greater proportion of households had similarly high levels of household security (p. 794). This is consistent with offenders being more likely to displace in areas with a higher proportion of insecure households. It is conceivable that the level of security in an area really determines what is sometimes termed collective efficacy.

A quantitative analysis of anti-burglary devices found that "combinations [of security devices] with door and window locks plus external lights or security chains confer at least 20 times greater protection against burglary with entry than 
no security." (Tseloni et al. 2016, p. 646). The study concluded that the decline in burglary in England and Wales from the early 1990s was attributable to the spread of insulated windows with double-paned glass, stronger frames and integrated locks, and to the spread of interior and exterior security lighting. Three main factors were identified as responsible for the decline in burglary. First, there was a rapid decline in the prevalence of households without any security devices. Second there was an increased use of good quality, that is, effective, security devices, particularly door and window deadlocks and security lighting. Third, there was greater use of combinations of such devices, and this was found to confer disproportionate protection (Tilley et al. 2015a; Tseloni et al. 2017). Note, however, that the effects of different security devices were found to vary greatly, including the finding that household alarms were ineffective in recent years (Tilley et al. 2015b), consistent with the better known fact that most alarm activations are false (Sampson 2007). Cross-national analyses of the International Crime Victims Survey had earlier shown that many European countries with declining burglary had increased rates of household security (van Dijk 2008; Sorensen 2003). Overall, while the timing and rate of spread of security differs between the US and Europe, as might be expected in different countries with different housing stock and differing burglary problems, there is a great deal of consistency in the international evidence from burglary studies.

Relatively recent interviews with expert burglars found that "Around half of our sample of burglars in 2006 had noticed increased security measures taken by householders in recent years, but the most common method of entry to their most recent target had been through an open window or door." (Nee 2015, p. 58). The low rate of burglaries at the time of the study suggests that by the 2000s, open doors and windows were rare, that even the older expert burglars had resorted to entering only through much sought-after open windows and doors, and that closed windows and doors were too secure even for experts (indicating good quality security devices in routine use). These findings resonate with the views of offenders in Australia who reported that security improvements were the most likely explanation for the property crime decline in that country (Brown 2015a, b).

Consistent with earlier studies, recent research finds offenders aware of cues indicating the age and quality of physical security measures. There are indications that expert burglars recognized the changes to household security that took place over time, one reporting "That [door] would be easy. The lock on that door looks like an old one. The newer ones have thicker handles around them and are harder to get through." (Armitage 2018, p. 296). Consistent with earlier findings, the same expert burglars reported burglar alarms were not a deterrent.

A study of burglaries that occurred between 2001 and 2005 in Newark, New Jersey, compared the location of burglaries and alarms (Lee and Wilson 2013). Both were found to be spatially concentrated but without significant overlap. Lee and Wilson interpret the lack of overlap as reflecting the effectiveness of alarms in reducing burglary and causing a spatial shift in burglary patterns, such that it remained 
primarily in non-alarmed areas. Elsewhere, surveillance and physical security were the design factors mentioned most by burglars (Armitage and Monchuk 2011; Armitage 2013).

Gated communities have been found to be diverse in nature but generally to reduce burglary (Addington and Rennison 2013). However, while the spread of gated communities may have reduced local burglary rates, their contribution to the US residential burglary decline remains undetermined. A more recent north American study found that spatial change in the distribution of burglaries, particularly that linked to buildings with entry key fobs, was consistent with that expected as the result of improvement to home security technologies. Specifically, it used "a spatial data signature between perceived access to home security technologies and declines in residential burglary to support the security hypothesis." (Hodgkinson and Andresen 2019, p. 98).

Smart household security is becoming more prevalent at the time of writing. A small but growing number of households include a suite of smart security with remote control and monitoring and remote video internally and for arrivals at the door, coordinated via smartphone apps. A review notes that household smart locks

let you receive alerts and track who's entering and leaving your abode; email limited-access digital "keys" to visitors, children, trusted service workers or guests when you're not home; and remotely lock and unlock when you're away from home... [Y] ou could program a night mode action that locks the doors and also turns off the lights and closes the shades. If a friend, family member or service worker rings your smart doorbell while you're away, you can visually confirm who it is via the smart doorbell, then remotely unlock the door to let them in. (Wolpin 2016)

Since experienced burglars often undertake checks for occupancy by knocking on the door, remote conversation may disrupt such checks, or at least provide photographic evidence of who arrived at the door. Manufacturers of smart household security also need to beware of interception, breach and hacking (Thomson 2016). That is, continued iterations of household security need to be secure to avoid adaptation by burglars that could result in renewed offender interest in household burglary. However, while we might hope that such recent developments may consolidate declines in burglary, they are too recent to have played a role in the longer-term decline.

\section{The population of burglars}

So far it has been shown that, when homes were insecure in the 1960s to 1980 s, burglars required little skill or experience. Most burglars were young. This section examines age using arrest data from the BJS and FBI, noting that previous studies have observed that the decline in burglary was disproportionately a decline in adolescent offending (Butts 2000; Snyder 2012).

Figure 2 shows how, across the years that burglary declined, there was an increase in the proportion of older, and a decrease in the proportion of younger, burglars. 
Fig. 2 Burglary arrests by age group 1960-2014 (Source: BJS, FBI)

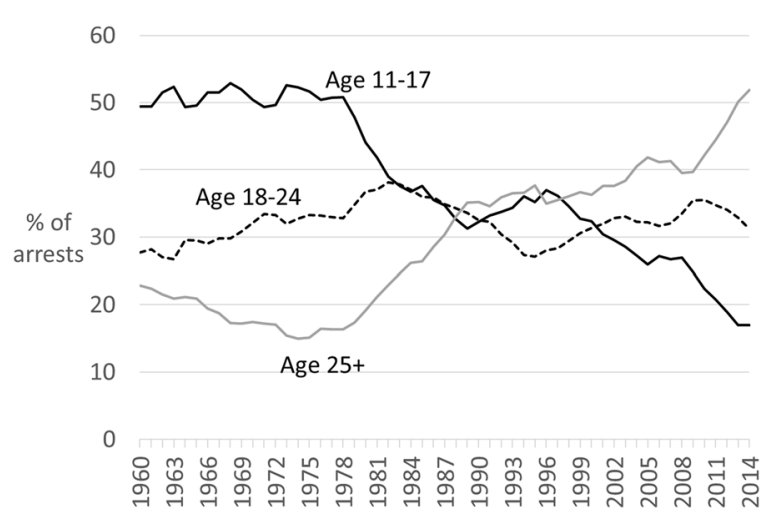

As a proportion of burglars arrested, between 1980 and 2010, those age under 17 declined from over $50 \%$ to less than $20 \%$ of those arrested, with a corresponding increase in burglars aged over 25. This is consistent with the younger, less experienced burglars, being more easily deterred. As household security improved over time, the proportion of older and more expert burglars increases. By the late 2010s, the average burglar was significantly older and more experienced. These trends are consistent with the range of studies examined so far that have touched on issues of burglar age, skill and experience.

The importance of the long-term change in age of burglars is straightforward. It provides a single over-time indicator spanning the decades of interest which corresponds with the other evidence.

\section{Discussion}

The primary justification for this study was the absence of reliable explanation for a major social phenomenon: the four-decade and over $80 \%$ decline in residential burglary in the US. The study's contribution is to provide an explanation, based on significant supporting evidence, to fill the gap in knowledge. The study identified a clear over-time progression in the narrative relating to burglary and security. In the 1970s, household security was sparse and ineffective whereas by the 2000s there was more and better security. The first two columns of Table 1 summarize aspects of household security of the 1970s and 1980s that were identified as important. First, the prevalence of security used to be low and few households had much if any security (Reppetto's 1974; Bureau of Justice Statistics 1985; Winchester and Jackson 1982; Rengert and Wasilchick 1985; Cromwell et al. 1991; Shover 1991). Second, the importance of insufficient or partial coverage of households was identified (Repetto 1974; Winchester and Jackson 1982; Bureau of Justice Statistics 1985; Rengert and Wasilchick 1985; Cromwell et al. 1991; Shover 1991). Third, security quality was low and it was easily overcome-windows and door were 'jimmied', frames and single-pane glass easily broken to gain entry (Repetto 1974; Winchester and Jackson 1982; Bureau of Justice Statistics 1985; Rengert and Wasilchick 1985; 


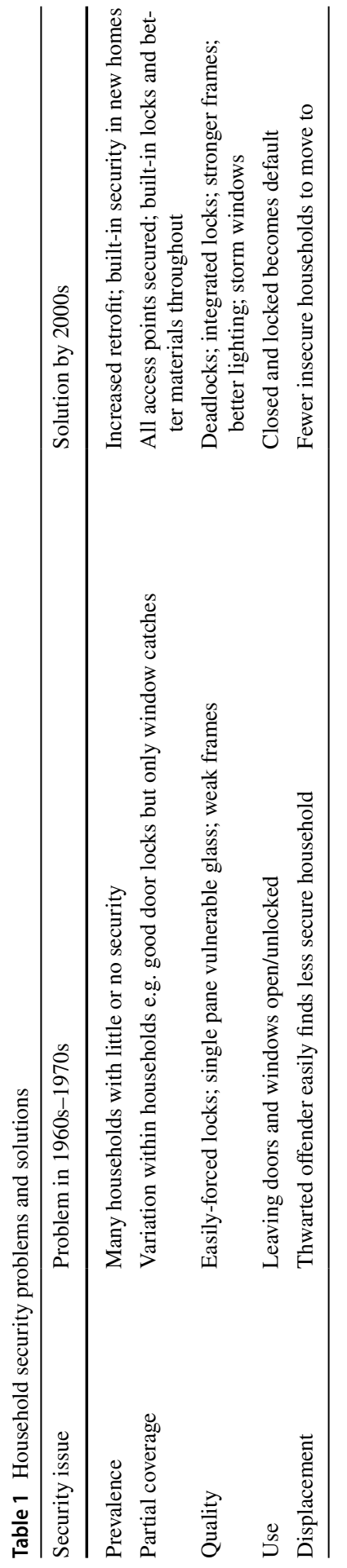

s. 
Cromwell et al. 1991, Shover 1991). Fourth, even where decent security existed, doors and windows were often left unlocked (Repetto 1974; Bureau of Justice Statistics 1985; Winchester and Jackson 1982; Rengert and Wasilchick 1985; Cromwell et al. 1991; Shover 1991). In addition, there was evidence that while displacement used to be easy when many insecure households were available as alternative targets (Bennett and Wright 1984; Rengert and Wasilchick 1985; Shover 1991), it became more difficult and less likely to occur as households became more secure (Nee and Meenaghan 2006). The major change over time in the average age of burglars is consistent with the expected effect of improved household security in reducing the involvement of juveniles more than older offenders.

The means by which it is suggested security improvements were achieved over time are summarized in the third column of Table 1. As the market for household security expanded, it brought new buyers and sellers, stimulating more and better security technologies (with stronger materials and more resistant locks). Over time, as competition and economies of scale lowered per-unit prices, previously 'special' security devices became routine precautions (Felson and Clarke 1995). This is consistent with a product lifecycle as demand increases, and with the nature of the diffusion of technology (Rogers 1962). As the prevalence of security increased, so too did its quality and coverage, its routine use, and the use of combinations of devices at the same household. Over time, households became increasingly likely to include integrated deadlocks and locks in doors and windows which had stronger frames, multiple panes of more resistant glass, and other built-in security devices. This made crime displacement increasingly difficult, burglars needing more time and expertise to locate and enter fewer insecure households.

By the third decade of the twenty-first century, the problem of burglary has been significantly addressed, but is far from solved. An increasing proportion of households are more secure by default. This is evident in how different security devices work in different ways, the more dramatic effect of multiple devices, and the aging of burglars as household security improved. It has been suggested that, as burglary has declined, the responsible security has become increasingly elegant, increasing rather than reducing liberty and quality of life (Farrell and Tilley 2020).

While the pace and extent of change to household security will have varied significantly from one region, city, town or area to the next, and in many instances from one household to the next, such variation would be around a national mean. Further research to examine such variation has the potential to complement the present study.

It is clear that some types of security device are more effective than others. Effectiveness will also vary between brands for different types of device: this was reported by offenders in relation to locks (some avoiding 'difficult' locks such as 'Chubbs'). With respect to particular devices, the evidence suggests stronger door and windows panels, frames and locks, and security lighting are effective, but alarms less effective or ineffective, and such nuances are important in relation to potential implications for the multi-billion dollar security industry.

Security, insurance and housing industry records are potentially rich sources of information on security product sales by types, model and make, the Standards and tests required, and the history of the evolution of devices: Churchill (2016) and 
others demonstrate the value of researching the history of security. Industry records may indicate sales of particular locks and types of windows, doors and materials. Archival research and the examination of the timing and nature of lock and security light patents may provide useful indicators of change over time.

Further investigation of the best ways to promote the development and implementation of security would seem appropriate. This indicates the need for further incentivization of industry-ncluding but not limited to the construction industry, security device and fittings manufacturers and the home insurance industry. In addition to measures to address burglary, this approach may prove fruitful in relation to industry whose products and work affects a wide range of crime types (Tilley 2018).

\section{Conclusion}

This study offers an explanation for a major social phenomenon on: the $80 \%$ decline in US residential burglary spanning four decades. The study examined burglary research spanning five decades and found that a consistent picture emerged. Almost as remarkable was the lack of identifiable contrary evidence. The likelihood that the findings have emerged from diverse studies and methods due to chance seems remote. Hence, the main conclusion of this study is that household security improvements played the central role in the long-term decline in US residential burglary. This conclusion squares well with previous research into the security hypothesis for other countries and crime types, and so while additional research evidence is always to be preferred, it seems reasonable to suggest that the burden of proof now lies with others to challenge this explanation or provide compelling evidence for an alternative.

The evidence suggested that four aspects of household security change played a central role: (1) the increased prevalence of security, (2) better quality, that is more robust and effective, security devices and fittings, (3) increasingly uniform security coverage within households and, (4) greater routine use of security devices. As a result, there was reduced likelihood of offender displacement. The relative contributions of these features is something that future research might examine.

This study approached the subject chronologically. This facilitated a reinterpretation of the burglary literature, and helped reconcile seemingly diverse findings. While the earlier burglary literature had little positive to say about household security, more recent studies made clear that even older expert burglars had developed a begrudging respect.

The study identified the disproportionate impact of security improvements upon crime by younger offenders. This suggests promising avenues for juvenile crime and justice research. Put simply, making crime more difficult to commit may be the most effective way to reduce juvenile crime and progression to adult crime. In the longterm, this continues to reduce juvenile and adult justice costs as fewer offenders enter the system and do so less frequently. To suggest that reducing crime opportunities is likely to be the most effective means of reducing juvenile crime and criminal careers is, of course, quite a significant challenge to orthodox views on this topic 
and on crime in general. It suggests that consideration of the role of security, and of reducing crime opportunities more generally, should be more central in crime theories, research and policy than they are at present.

Absent complacency, household security in the US and elsewhere should continue to improve, reflecting housing market expansion and churn as older homes are replaced or refurbished, and as economies of scale and competition further reduce the price of security fixtures and fittings. The development of technology that avoids or reduces crime opportunities represents society's main comparative advantage over offenders. The growth of smart security suggests the possibility for new offender means of entry to households using hacking and social engineering. Assuming smart security overcomes such threats and is effective, it should also decline in price and become more widespread. This all suggests that the next generation of crime research should consider more extensive routine measurement of security of different types in different sectors of society.

Acknowledgements The author acknowledges repeated fundings from the Economic and Social Research Council to study the international crime drop (grants RES-000-22-2386, ES/K003771, ES/L014971). He would like to thank Alexia Cooper of the Bureau of Justice Statistics for advice that facilitated obtaining the older arrest data from the FBI.

\section{Compliance with ethical standards}

Conflict of interest The author states that there is no conflict of interest.

Open Access This article is licensed under a Creative Commons Attribution 4.0 International License, which permits use, sharing, adaptation, distribution and reproduction in any medium or format, as long as you give appropriate credit to the original author(s) and the source, provide a link to the Creative Commons licence, and indicate if changes were made. The images or other third party material in this article are included in the article's Creative Commons licence, unless indicated otherwise in a credit line to the material. If material is not included in the article's Creative Commons licence and your intended use is not permitted by statutory regulation or exceeds the permitted use, you will need to obtain permission directly from the copyright holder. To view a copy of this licence, visit http://creativecommons.org/licen ses/by/4.0/.

\section{References}

Addington, L.A., and C.M. Rennison. 2013. Keeping the barbarians outside the gate? Comparing burglary victimization in gated and non-gated communities. Justice Quarterly 32 (1): 168-192.

Armitage, R. 2013. Crime prevention through housing design: Policy and practice. London: Palgrave Macmillan.

Armitage, R. 2018. Burglars' take on crime prevention through environmental design (CPTED): Reconsidering the relevance from an offender perspective. Security Journal 31 (1): 285-304.

Armitage, R., and L. Monchuk. 2011. Sustaining the crime reduction impact of designing out crime: Reevaluating the Secured by Design scheme 10 years on. Security Journal 24 (4): 320-343.

Bässmann, J. 2011. Vehicle theft reduction in Germany: The long-term effectiveness of electronic immobilisation. European Journal of Criminal Policy Research 17: 221-246.

Bastion, L.D. 1992. Crime and the Nation's households, 1991. Bureau of Justice Statistics Bulletin. Washington: Bureau of Justice Statistics, U.S. Department of Justice. 
Beaton, A., M. Cook, M. Kavanagh, and C. Herrington. 2000. The psychological impact of burglary. Psychology, Crime \& Law 6: 33-43.

Bennett, T., and R. Wright. 1984. Burglars on Burglary. Aldershot: Gower.

Biderman, A.D., and J.P. Lynch. 1991. Understanding crime incidence statistics: Why the UCR diverges from the NCS. New York: Springer-Verlag.

Blumstein, A., J. Cohen, J.A. Roth, and C.A. Visher, eds. 1986. Criminal careers and 'career criminals', vol. 1. Washington: National Academy Press.

Bowers, K., and S.D. Johnson. 2017. Burglary prevention in practice. In Handbook of crime prevention and community safety, 2nd ed., ed. N. Tilley and A. Sidebottom, 319-353. London/New York: Routledge.

Brown, R. 2015a. Reviewing the effectiveness of electronic vehicle immobilisation: Evidence from four countries. Security Journal 28 (4): 329-351.

Brown, R. 2015b. Explaining the property crime drop: the offender perspective. Trends and Issues in Crime and Justice No. 495. Canberra: Australian Institute of Criminology.

Brown, B.B., and P.B. Harris. 1989. Residential burglary victimization: Reactions to the invasion of a primary territory. Journal of Environmental Psychology 9: 119-132.

Budd, T. 1999. Burglary of Domestic Dwellings: Findings from the British Crime Survey. Home Office Statistical Bulletin 04/99. London: Home Office.

Bureau of Justice Statistics. 1985. Household burglary. Bureau of Justice Statistics Bulletin. Washington: Bureau of Justice Statistics, U.S. Department of Justice.

Butts, J.A. 2000. Youth crime drop. Urban Institute Justice Policy Center: Washington D.C.

Churchill, D. 2016. The spectacle of security: Lock picking competitions and the security industry in mid-Victorian Britain. History Workshop Journal 80 (1): 52-74.

Clarke, R.V. 2012. Opportunity makes the thief. Really? And so what? Crime Science 1 (2): 1-9.

Clarke, R.V. 2017. Situational crime prevention. In Environmental Criminology and Crime Analysis, 2nd ed., ed. R. Wortley and M. Townsley. London: Routledge.

Cohen, M.A. 2000. Measuring the costs and benefits of crime and justice, Measurement and analysis of crime and justice. In Criminal Justice, vol 4. Washington DC: National Institute of Justice.

Cohen, L.E., and M. Felson. 1979. 'Social change and crime rate trends: A routine activity approach. American Sociological Review 44 (4): 588-608.

Cornish, D.B., and R.V. Clarke. 1986. The reasoning criminal: Rational choice perspectives on offending. The Hague: Springer-Verlag.

Cromwell, P.F., J.N. Olson, and D.W. Avary. 1991. Breaking and entering: An ethnographic analysis of burglary. Newbury Park: Sage.

Dixon, A., and G. Farrell. 2020. Age-period-cohort effects for half a century of motor vehicle theft in the United States. Crime Science 9 (11): 1-17.

Farrell, G. 2013. Five tests for a theory of the crime drop. Crime Science 2 (5): 1-8.

Farrell, G., and N. Tilley. 2020. Elegant security: Concept, evidence and implications. European Journal of Criminology. https://doi.org/10.1177/1477370820932107.

Farrell, G., N. Tilley, and A. Tseloni. 2014. Why the crime drop? In Why Crime Rates Fall and Why They Don't, volume 43 of Crime and Justice: A review of research, ed. M. Tonry, 421-490. Chicago: University of Chicago Press.

Farrell, G., A. Tseloni, J. Mailley, and N. Tilley. 2011. The crime drop and the security hypothesis. Journal of Research in Crime and Delinquency 48 (2): 147-175.

Farrington, D.P. 1986. Age and crime. In Crime and justice: An annual review of research, ed. M. Tonry and N. Morris, 189-251. Chicago: University of Chicago Press.

Felson, M., and R.V. Clarke. 1995. Routine precautions, criminology and crime prevention. In Crime and Public Policy, ed. H.D. Barlow, 120-128. New York: Springer Verlag.

Felson, M., and R.V. Clarke. 1998. Opportunity makes the thief: Practical theory for crime prevention. Police Research series paper 98. London: Home Office.

Fujita, S., and M. Maxfield. 2012. Security and the drop in car theft in the United States. In The International Crime Drop: New Directions in Research, ed. J.J.M. van Dijk, A. Tseloni, and G. Farrell. London: Palgrave Macmillan.

Garafalo, J., and D. Clarke. 1992. Guardianship and residential burglary. Justice Quarterly 9 (3): 443-463.

Grove, L.E., G. Farrell, D.P. Farrington, and S.D. Johnson. 2012. Preventing repeat victimization: A systematic review. Stockholm: Swedish National Council for Crime Prevention. 
Hodgkinson, T., and M.A. Andresen. 2019. Changing spatial patterns of residential burglary and the crime drop: The need for spatial data signatures. Journal of Criminal Justice 61: 90-100.

Kriven, S., and E. Ziersch. 2007. New car security and shifting vehicle theft patterns in Australia. Security Journal 20: 111-122.

Lauritsen, J.L., M.L. Rezey, and K. Heimer. 2016. When choice of data matters: Analyses of U.S. crime trends, 1973-2012. Journal of Quantitative Criminology 32: 335-355.

Lee, S., and H. Wilson. 2013. Spatial impact of burglary alarms on the decline of residential burglary. Security Journal 26 (2): 180-198.

Lynch, J.P., and L.A. Addington. 2007. Understanding crime statistics: Revisiting the diverge of the NCVS and UCR. New York: Cambridge University Press.

Macmillan, R. 2000. Adolescent victimization and income deficits in adulthood: Rethinking the costs of criminal violence from a life course perspective. Criminology 38: 553-588.

Maguire, M., and T. Bennett. 1982. Burglary in a dwelling: The offence, the offender and the victim. London: Heinemann.

Mawby, R.I. 2001. Burglary. Portland: Willan.

Mayhew, P. 1987. Residential burglary: A comparison of the United States, Canada and England and Wales. Washington: Department of Justice, National Institute of Justice.

Miller, T.R., M.A. Cohen, and B. Wiersema. 1996. Victim costs and consequences: A new look. Washington: Department of Justice, National Institute of Justice.

Nee, C. 2015. Understanding expertise in burglars: From pre-conscious scanning to action and beyond. Aggression and Violent Behavior 20: 53-61.

Nee, C., and A. Meenaghan. 2006. Expert decision-making in burglars. British Journal of Criminology 46: 935-949.

Owen, N., and C. Cooper. 2013. TThe start of a criminal career: Does the type of debut offence predict future offending? London: Home Office.

Pease, K. 1991. The Kirkholt project: Preventing burglary on a British public housing estate. Security Journal 2 (2): 73-77.

Perez, J. 1992. Patterns of robbery and burglary in 9 States, 1984-88. Bureau of Justice Statistics Special Report. Washington D.C.: U.S. Department of Justice.

Piquero, A., and S. Tibbetts, eds. 2002. Rational choice and criminal behavior. New York: Routledge.

President's Commission on Law Enforcement and Administration of Justice. 1967. The challenge of crime in a free society. Washington: Government Printing Office.

Rand, M.R., J.P. Lynch, and D. Cantor. 1997. Criminal Victimization, 1973-1995. Washington D.C.: Bureau of Justice Statistics, U.S. Department of Justice Office of Justice Programs. (NCJ-163069).

Rengert, G., and J. Wasilchick. 1985. Suburban burglary: A time and a place for everything. Illinois: Charles C. Thomas.

Reppetto, T.A. 1974. Residential crime. Cambridge: Ballinger.

Reppetto, T.A. 1984. Police anti-burglary strategies in the United States. In Coping with Burglary, ed. R. Clarke and T. Hope, 155-167. Boston: Kluwer-Nijhoff.

Rogers, E.M. 1962. Diffusion of innovations. New York: Free Press.

Sampson, R. 2007. False Burglar alarms, Second Edition. Problem Specific Guide No. 5. Washington D.C.: Community Oriented Policing Services.

Shover, N. 1991. Burglary. Crime and Justice 14: 73-113.

Snyder, H. 2012. Arrest in the United States 1990-2010. Washington D.C.: Bureau of Justice Statistics. (NCJ 239423).

Snyder, H., A.D. Cooper, and J. Mulako-Wangota. 2017. Arrest in the United States, 1980-2014. Generated using the arrest data analysis tool. www.bjs.gov. Accessed 06 Oct 2018.

Sorensen, D. 2003. The nature and prevention of residential burglary: A review of the international literature with an eye toward prevention in Denmark. Faculty of Law: University of Copenhagen.

Thomson, I. 2016. 'If you use 'smart' Bluetooth locks you're asking to be burgled' The Register, 08 August 2015. http://www.theregister.co.uk/2016/08/08/using_a_smart_bluetooth_lock_to_prote ct_your_valuables_youre_an_idiot/. Accessed 10 Aug 2016.

Tilley, N. 2018. Privatising crime control. Annals of the American Academy of Political and Social Science. 679 (1): 55-71.

Tilley, N., A. Tseloni, and G. Farrell. 2011. Income disparities of burglary risk: Security availability during the crime drop. British Journal of Criminology 51: 296-313.

Tilley, N., G. Farrell, and R.V. Clarke. 2015. Target suitability and the crime drop. In Routine activities and the Criminal Act, ed. M. Andresen and G. Farrell, 59-76. London: Palgrave Macmillan. 
Tilley, N., G. Farrell, L.E. Grove, R. Thompson, and A. Tseloni. 2015. Do burglar alarms increase burglary risk? A counterintuitive finding and possible explanation. Crime Prevention and Community Safety: An International Journal 17 (1): 1-19.

Titus, R. 1999. Declining residential burglary rates in the USA. Security Journal 12 (4): 59-63.

Tseloni, A., R. Thompson, L.E. Grove, N. Tilley, and G. Farrell. 2016. The effectiveness of burglary security devices. Security Journal 30 (2): 646-664.

Tseloni, A., G. Farrell, R. Thompson, E. Evans, L.E. Grove, and N. Tilley. 2017. Domestic burglary drop and the security hypothesis. Crime Science 6 (3): 1-16.

U.S. Census Bureau. 2018. Current Population Survey, March and Annual Social and Economic Supplements. https://www.census.gov/programs-surveys/cps/technical-documentation/complete.html. Accessed 30 Oct 2018.

Van Dijk, J.J.M. 2008. The World of Crime. London: Sage.

Van Ours, J.C., and B. Vollaard. 2016. The engine immobiliser: A non-starter for car thieves. Economic Journal 126 (593): 1264-1291.

Vollaard, B., and J.C. van Ours. 2011. Does regulation of built-in security reduce crime? Evidence from a natural experiment. Economic Journal 121 (552): 486-504.

Waller, I., and N. Okihiro. 1978. Burglary: The Victim and the Public. Toronto: University of Toronto Press.

Walters, J.H., A. Moore, M. Berzofsky, and L. Langton. 2013. Household burglary 1994-2011. Washington: Bureau of Justice Statistics.

Weisel, D.L. 2005. Burglary of single-family houses. Problem-Oriented Guide for Police Series No. 18. Washington D.C.: U.S. Department of Justice.

Wickramasekera, N., J. Wright, H. Elsey, J. Murray, and S. Tubeauf. 2015. Cost of crime: A systematic review. Journal of Criminal Justice 43: 218-228.

Wilcox, P., T.D. Madensen, and M. SkubakTillyer. 2007. Guardianship in context: Implications for burglary victimization risk and prevention. Criminology 45 (4): 771-803.

Winchester, S. and H. Jackson. 1982. Residential Burglary: The Limits of Prevention. Home Office Research Study No. 74. London: Her Majesty's Stationery Office.

Winkel, F.W., and A. Vrij. 1993. Facilitating problem- and emotion-focused coping in victims of burglary: Evaluating a police crisis intervention program. Journal of Community Psychology 21 (2): 97-112.

Wolpin, S. 2016. 5 best smart locks for your home, Techlicious. http://www.techlicious.com/guide/5-futur istic-smart-locks-for-your-home/. Accessed 10 Aug 2016.

Wright, R.W., and S. Decker. 1994. Burglars on the job: Streetlife and residential break-ins. Boston: Northeastern University Press.

Publisher's Note Springer Nature remains neutral with regard to jurisdictional claims in published maps and institutional affiliations. 